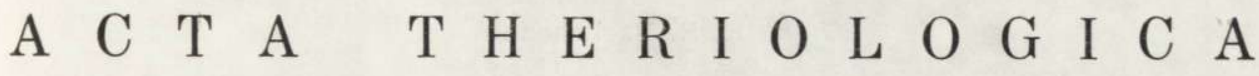

VOL. 18, 20: 395-402.

BIAŁOWIEŻA

December, 1973

Kyle R. B A R B E HE N N

\section{The Use of Stratified Traps in Estimating Density: Peromyscus and Blarina}

[With 2 Tables]

\begin{abstract}
Snap traps were set on the surface of the leaf litter, across excavated burrows, and in circular ditches in a mesic hardwood forest in Maryland. Over a thirty-day period, the overall rate of capture for Blarina brevicauda and Peromyscus leucopus was very similar-50\% of the total catch of each was taken on day-6. However, 19/28 shrews and only $1 / 16$ mice were taken in burrows. Apparently trap position can influence the rate of capture and, to reduce behavioral bias in achieving rapid estimates of density, it is suggested that traps be vertically stratified. Stratifying traps horizontaly to include more restricted portions of the micro-habitat should be tested experimentally with standard methods.
\end{abstract}

\section{INTRODUCTION}

The development of a standard way to determine the density of small mammals (Grodziński, Pucek \& Ryszkowski, 1966) has been hampered by the fact that, during the first few days of removal trapping, some species of small mammals may be taken at very low rates relative to their actual abundance (G e n try, G o ll e y \& S m i t h, $1968,1971)$. C a l houn $(1959,1964)$ suggested that such lags in catch were due to community organization - the presence of a psychologically dominant species seems to inhibit the movements of some subordinate species, in effect preventing them from encountering traps until inhibitions are relased by the removal of the more dominant species. Noting that some of these »difficult-to-trap " species are readily taken by pitfalls, other workers (Fow le \& Edwards, 1954; P ucek, 1969 ; Faust, Smith \& Wray, 1971) have suggested that the lag in catch is caused by a "strange object reaction ". While there is some truth to both hypotheses, I suggest here that one major reason for the lag is that the activities of various cohabiting species are vertically stratified and that the most appropriate method for countering the bias is to stratify traps accordingly. 
There is nothing new about the concept of stratifying traps. No rational worker would expect to catch many flying squirrels (Sciuridae) or pocket gophers (Geomyidae) in traps set on the surface of the ground, and the Polish Standard Minimum Method is not designed to sample such deviant species. The major conceptual problem is with species that spend variable amounts of their time on the surface. Thus, Strecker (1962) and L i m (1970) found that traps set on the trunks and branches of trees caught certain species of Rattus with greater relative frequency than traps set on the ground. Olszewski (1968) found that traps set on fallen trees took relatively more Apodemus while those set on the ground below the trees tock relatively more Clethrionomys. In temperate regions, most of the more "difficult" species include various shrews (Soricidae) and voles (Microtinae), and one solution to the problem is to use pitfalls in association with conventional traps (e.g., B u c h a lczyk \& Pucek, 1968; and Pucek, 1969). In effect, while it does have other properties, a pitfall is an example of stratified trap.

My experience with the shrew, Blarina brevicauda, in old-field habitats disclosed no lag in catch when traps were set in surface runways made, for the most part, by Microtus pennsylvanicus ( $\mathrm{B}$ a $\mathrm{r}$ behen $\mathrm{n}$, 1958). Catches of this shrew were avoided, even in pre-baited spots, by simply setting live traps on top of the ground-covering litter a few $\mathrm{cm}$ from the runway. Similarly, workers with Blarina in forest habitats (Hamilton, 1943; Buckner, 1966) indicate that most of this shrew's activity is spent in subsurface burrows and experience from extended trapping has been that surface activity of shrews is increased by removing Peromyscus ( $\mathrm{Calhoun}, 1964$ : 76). It follows that the frequent lag in catch for Blarina in forest situations may be avoided by setting traps in partially excavated burrows. A preliminary test of this hypothesis was conducted many years ago as part of an attempt to develop standard methods for studying community organization. Since the major focus of many recent workers is to reduce the bias of density estimates from short term trapping presenting the results at this time may encourage other to test this possible solution to the lag in capture.

\section{AREA AND METHODS}

Trapping was conducted in a mesic hardwood forest in rolling terrain near Rockville, Maryland. Two octagons (Calhoun, 1959) each with 40 trapping stations spaced $7.5 \mathrm{~m}$ apart were established. Snap traps $(47 \times 98 \mathrm{~mm})$ were utilized in two forms: with and without shields. Shields of galvanized sheet metal (painted brown) were designed to protect traps from rain and falling debris. The base of the shield measured approximately $50 \times 100 \mathrm{~mm}$ and the upper portion was bent on an angle such that the roof was parallel to the base and 
just high enough $(60 \mathrm{~mm})$ to provide clearance for the killing bar. Individual traps were bolted to the shields with the trigger facing outward. Shielded and plain traps were set in groups of three in alternate stations along the lines.

Three methods of placing traps were used: 1) on the surface, 2) across burrows, and 3 ) in ditches. Positions of surface traps were determined by randomly dropping a device with three arms, each $75 \mathrm{~cm}$ long and 120 degrees apart. One trap, with the treadle pointed away from the center, was placed at the distal end of each arm. Burrows were located by probing with fingers in the leaf litter and mineral soil at locations approximately comparable to that of the surface traps. Burrows, if found, were partially excavated and a trap was placed with the treadle across the burrow, if possible. Shielded traps were often difficult to position satisfactorily in burrows. Circular ditches were made with the aid of a sheet-metal frame and knife. The inner edge of the ditch was $60 \mathrm{~cm}$ from the center of the station and the ditch was $15 \mathrm{~cm}$ wide. Leaf litter, humus and roots were cut along the edge of the frame and removed from the ditch, exposing the mineral soil. Traps were placed at equal distances around the circle inside the ditch without reference to any burrows that might have been exposed.

The three treatments were applied in repeated sequence along the lines and, in combination with the shield versus plain trap types, the total sequence included six consecutive stations. With a total of eighty stations, shield-surface and plain-burrow treatments occurred 14 times each while the remaining combinations occurred 13 times each.

Unbaited, unset traps were placed in position on 21 July 1959 to allow animals to accommodate to the "strange objects " and altered habitat. Traps were then baited with a mixture of peanut butter, rolled oats, chopped raisins and bacon fat and set on 28 July. Traps were checked for 30 consecutive days, replacing bait as necessary.

\section{RESULTS}

The 30-day catch produced 28 Blarina brevicauda, 16 Peromyscus leucopus, 1 Microtus (Pitymys) pinetorum and $1 \mathrm{M}$. pennsylvanicus, plus 2 birds, 1 box turtle, and a cicada killer (Hymenoptera). No differences in the pattern of catch were observed between the two octagons so results are pooled in Table 1 . In general, the small sample sizes preclude a detailed analysis but one conclusion is obvious. Placing traps across burrows is an excellent way to catch Blarina and a very poor way to catch Peromyscus. The relatively low catch of Blarina in shield-burrow combinations was probably due to the difficulty in positioning traps rather than to any avoidance of the shield. The ditches may have served to focus the movements of Peromyscus on the traps, as was intended, but the results are not convincing. A single pine vole (Pitymys) was taken in a burrow on day-2 suggesting that this species was relatively rare. A single Microtus pennsylvanicus, taken on day-21, was probably a transient from a field $150 \mathrm{~m}$ distant. 
Pooling all treatments, the number of Blarina caught during each of the first seven days was essentially constant while there was an apparent lag in catching Peromyscus - only one being caught during the first three days. For both common species, $50 \%$ of the 30 -day total was taken on day- 6 and, in general, no significant differences in the temporal pattern of catch was observed.

Table 1

The catch of shrews (Blarina) and mice (Peromyscus) as influenced by presence or absence of shields on traps and location of traps on the ground surface, across burrows, and in artificial ditches.

\begin{tabular}{llll}
\hline Surface & Burrow Ditch & Total \\
\hline
\end{tabular}

Blarina brevicauda

$\begin{array}{lrrrl}\text { Shield } & 2 & 3 & 5 & 10 \\ \text { No Shield } & 1 & 16 & 1 & 18 \\ \text { Total } & 3 & 19 & 6 & 28\end{array}$

Peromyscus leucopus

\begin{tabular}{lllrr} 
Shield & 1 & 0 & 5 & 6 \\
No Shield & 4 & 1 & 5 & 10 \\
Total & 5 & 1 & 10 & 16 \\
\hline
\end{tabular}

Table 2

Effects of metal shields on the number of traps sprung by factors other than known animal activity. For each class of traps, 120 were exposed each day.

\begin{tabular}{lcccc}
\hline $\begin{array}{l}\text { Weather } \\
\text { condition }\end{array}$ & $\begin{array}{c}\text { Number } \\
\text { of days }\end{array}$ & $\begin{array}{c}\text { Sprung traps } \\
\text { Shield }\end{array}$ & $\begin{array}{c}\text { No shield } \\
\text { Notal }\end{array}$ & Totar \\
\hline Rain & 5 & 25 & 159 & 184 \\
No Rain & 20 & 46 & 110 & 156 \\
Total & 25 & 71 & 269 & 340 \\
\hline
\end{tabular}

The procedures used here do not permit a strictly independent evaluation of trapping methods on the rate of capture. At a station interval of $7.5 \mathrm{~m}$ it seems likely that several sets of traps were included within the ranges of many individuals and a shrew caught in a burrow cannot then be taken elsewhere. No shrews were caught in surface traps until day- 8 . Of the 28 shrews caught, the temporal rank of those taken in surface traps was 19,25 , and $26(z=-1.97, p<.05)$. The implication is that, had all traps been set on the surface, relatively few shrews would have been trapped during the first week. 
The effectiveness of the shields in preventing accidental springing of traps was analyzed from records of sprung traps on 25 of the 30 days (Table 2). Unshielded traps were sprung at the rate of $4.6 \%$ on clear days and $26 \%$ on rainy days. Comparable values for shielded traps were 1.9 and $4.2 \%$ respectively. The efficacy of the shields in reducing accidental springing is unquestinonable but, since trap success was not enhanced by the shields (Table 1), their use seems generally impractical.

\section{DISCUSSION}

Historically, most of the small mammal trapping conducted in various parts of the world has been done by museum workers whose aim was to obtain a large catch, including the less common species, in a short period of time at a given locality. The method of laying traps usually varied with the local environment and with the operator's idea of what constituted a "good" place to set traps. Success was judged to be a matter of skill and competition among workers on a collecting foray was keen. The need for more objective appraisals of small mammal density, however, has tended to promote "standard " methods of laying traps that reduce operator variables. Unfortunately, arbitrary procedures in placing conventional traps may actually increase bias in evaluating community composition.

Pronounced lags in capturing shrews and certain other species are commonly observed with use of the Polish Standard Minimum method (e.g., Gentry, Golley \& Smith, 1971). While such results are of considerable interest from the viewpoint of understanding community organization ( $\mathrm{Calhoun}, 1964)$, the purpose of the SM method is to measure community composition efficiently. A modification of standard methods is in order and the use of pitfalls in addition to snap traps is a demonstrable improvement (e.g., P u c e k, 1968). Pitfalls, however, may be impractical in either rocky or poorly drained situations.

$\mathrm{Smith}$ et al. (1971) have attempted to solve the problem by extended trapping followed by accessory assessment lines to estimate the area from which animals have been removed, but I have judged this procedure to be impractical ( $\mathrm{B}$ a $\mathrm{rb}$ e he $\mathrm{n} n$, in preparation). The alternative of stratifying traps, as demonstrated here, serves to reduce much of the lag in catch for species that spend much of their time either above or below the surface of the ground. Additional testing is necessary. It should be emphasized, however, that species conforming to $\mathrm{C}$ a lh o u n's (1964) home range model of inhibition will still cause problems. (B a r b e h en n, 1969). 
A second modification in procedures is suggested by Olszewski's (1968) results. Not only did he find that Apodemus made greater use of the trunks of fallen trees than did Clethrionomys but, in addition, Apodemus was much more likely to be caught in traps set independently of fallen trees than was Clethrionomys. The implication is that microhabitat varies horizontally as well as vertically in a forest and, if the movements of certain species are confined to special features of the environment, an arbitrary placement of traps may not sample such situations adequately. An appropriate solution may be to establish grid stations systematically but give the operator freedom to set additional traps at what he judges to be the optimal location within $5 \mathrm{~m}$ of the grid point. A separate analysis of arbitrary versus selected sites will soon indicate whether or not animals are moving randomly and how well the operator can interpret the microhabitat. A combination of horizontal and vertical stratification of traps should provide a more accurate measure of the small mammal community with short-term trapping.

It may be argued that operator differences in selecting "good " trap positions will introduce a bias in the results, but it is already clear that an arbitrary positioning of the traps may produce its own bias. There is little point in waiting up to 30 days for community organization to be destroyed if equally good results can be obtained from modified procedures in a short period of time.

Acknowledgements: The above research was done in collaboration with Dr. John B. $\mathrm{Calh}$ oun and was supported by a fellowship, MF-9528, from the National Institute of Mental Health. We thank Mr. M. F. R u p pert for permission to work on his land. Preparation of the manuscript was supported by U.S.P.H.S. 5 P 10 ES 00139 .

\section{REFERENCES}

1. Barbehenn K. R., 1958: Spatial and population relationships between Microtus and Blarina. Ecology, 39: 293-304.

2. B a rbehenn K. R., 1969: Responses of rodents and shrews to patterns of removal trapping [In: D. W. P a r a ck (convener), "Indian Rodent Symposium, December 8-11, 1966 «]. India: 247-252.

3. B uchalczyk T. \& Pucek Z., 1968: Estimation of the numbers of Microtus oeconomus using the Standard Minimum method. Acta theriol., 13: 461-482.

4. Buckner C. H., 1966: Populations and ecological relationships of shrews in tamarack bogs of southeastern Monitoba. J. Mamm., 47: 181-194.

5. Calhoun J. B. (ed.), 1959: Revised sampling procedure for the North American Census of Small Mammals (NACSM). Population Dynamics of Vertebrates. Release No. 10: 1-12. Admin. Publ. U. S. Dep. of Health, Education \& Welfare. Bethesda, Maryland.

6. Calhoun J. B., 1964: The social use of space [In: W. M a yer and R. G. Van Gelder (eds.), "Physiological Mammalogy«]. 1: 1-187. Academic Press, New York. 
7. Faust B. F., Smith M. H. \& Wray W. F., 1971: Distances moved by small mammals as an apparent function of grid size. Acta theriol., 16: 161-177.

8. Fowle C. D. \& Ed wards R. Y., 1954: The utility of break-back traps in population studies of small mammals. J. Wildlife Mgmt., 18: 503-508.

9. Gentry J. B., Golley F. G. \& Smith M. H., 1968: An evaluation of the proposed International Biological Program census method for estimating small mammal populations. Acta theriol., 13: 313-327.

10. Gentry J. B., Goliey F. G. \& Smith M. H., 1971: Yearly fluctuations in small mammai populations in a southeastern United States hardwood forest. Acta theriol., 16: 179-190.

11. Grodziński W., Pucek Z. \& Ryszkowski L., 1966: Estimation of rodent numbers by means of prebaiting and intensive removal. Acta theriol., 1: $297-314$.

12. Hamilton W. J. Jr., 1943: "The Mammals of Eastern United States". Comstock Publ. Co.: 1-432. Ithaca, New York.

13. Li m B. L., 1970: Distribution, relative abundance, food habits, and parasite patterns of giant rats (Rattus) in West Malaysia. J. Mamm., 51: 730-740.

14. Olszewski J. L., 1968: Role of uprooted trees in the movement of rodents in forests. Oikos, 19: 99-104.

15. Pucek Z., 1969. Trap response and estimation of numbers of shrews in removal catches. Acta theriol., 14: 403-426.

16. Smith M. H., Blessing R., Chelton J. G., Gentry J. B., Golle y F. B. \& McGinnis J. T., 1971: Determining density for small mammal populations using a grid and assessment lines. Acta theriol., 16: 105-125.

17. Strecker R. L., 1962: XI. Economic relations. A. Coconut groves. [In: T. I. Storer (ed.), "Pacific Island rat ecology«]. B. P. Bishop Mus. Bull. 225: 200-208. Honolulu, Hawaii.

Accepted, May 15, 1973.

Center for the Biology of Natural System,

Washington University,

Saint Louis, Missouri 63130, U.S.A.

Kyle R. BARBEHENN

\section{WARSTWOWY UKŁAD PUEAPEK DO OCENY ZAGESZCZENIA PEROMYSCUS I BLARINA}

\section{Streszczenie}

Pułapki zabijające rozmieszczono na powierzchni ścioły, w rozkopanych norach oraz $\mathrm{w}$ kolistych rowach. Powierzchnie odłowne ustawione były w mezotroficznym lesie liściastym w stanie Maryland. W ciągu 30 dni tempo wyłowu Blarina brevicauda i Peromyscu leucopus było bardzo podobne, gdyż w początkowych 6 dniach złowiło się $50 \%$ ogólnej liczby zwierząt. Jednakże 19 na 28 złowionych ryjówek 
i zaledwie 1 z 16 myszy schwytano w norach (Tabela 1). Zatem położenie pułapki może oddziaływać na tempo wyłowu. By więc przy szybkich oznaczeniach zagęszczenia, zredukować wpływ behavioru na wskaźniki łowności, należy warstwowo zróżnicować położenie pułapek.

Należałoby też zbadać w sposób standardowy jaka jest łowność zależnie od określonych warunków mikrośrodowiska. 